\title{
Guanxi, a two-edged sword! How Australian accounting professionals view the process within a moral framework
}

\author{
Ying Han Fan (PhD) \\ Lecturer \\ School of Accounting \\ Curtin University \\ Y.Fan@curtin.edu.au \\ Gordon Woodbine (PhD) \\ Senior Lecturer \\ School of Accounting \\ Curtin University \\ Gordon.Woodbine@cbs.curtin.edu.au \\ Glennda Scully $(\mathrm{PhD})$ \\ Associate Professor \\ School of Accounting \\ Curtin University \\ Glennda.Scully@cbs.curtin.edu.au
}

\section{Correspondence Details}

Dr. Ying Han Fan

School of Accounting

Curtin University of Technology

GPO Box U1987

Perth, Western Australia

Phone: 61892662857

Fax: $\quad 61892667196$

Email: Y.Fan@curtin.edu.au 


\title{
Guanxi, a two-edged sword! How Australian accounting professionals view the process within a moral framework
}

\begin{abstract}
:
Purpose - The purpose of this study is to determine how western business practitioners, specifically Australian accounting professionals identify with the Chinese value concept of guanxi and the impact of their perceptions of guanxi on their ethical decision-making. This objective is predicated by a belief that aspects of guanxi are similar to the western concept of social networking and would be identified by practitioners as an organizational process providing positive benefits to those associated with its application. Further it is anticipated that concepts of guanxi influence the way Australian accountants form ethical judgments and intentions, precursors to acceptable moral behaviour.

Design/methodology/approach - Cross-sectional questionnaire based survey of 111 usable Australian accounting professionals completed during 2012. A confirmatory factor analysis was employed to validate each construct of guanxi before a path analysis was performed.

Findings - Australian accounting professionals associate well with the favour-seeking aspects of guanxi, suggesting an affiliation with western concepts of social networking. Both groups (i.e., public accountants and private accountants) reject rent-seeking guanxi as clearly unethical. Rentseeking guanxi is seen to directly influence ethical judgment and intention; however, their favour-seeking guanxi attitudes do not influence ethical judgment or intention, regardless of employment type.

Public and private accountants apply guanxi in a differential manner when determining moral intention. Public accountants are viewed as acting spontaneously without adequately considering the consequences (via the judgment phase), which appears to be a function of the nature of their personal association with the case study applied in this research.

Originality/value - The research provides evidence that Australian accounting professionals relate to favour-seeking guanxi as representative of a broader notion of social networking. In this context, the guanxi instrument appears to be amenable to cross-cultural evaluations of group behaviour. Significant differences of opinion exist compared to the prior Chinese studies when unethical practices are considered. The guanxi instrument proves to be a useful tool when examining the group interactions involving western professionals and also helps establish differences in moral constructions based on employment types.
\end{abstract}

Keywords Guanxi, western social network theory, ethical judgment and intention, Australian accounting professionals

Paper type - Research paper 


\section{Introduction}

Ethical decision-making is a complex process that is influenced by numerous factors including personal values, external influences (Hunt and Vitell, 1986; 1993) and situations related to the issues (Jones and Kavanagh, 1996). Personal connections or interpersonal relationships such as guanxi are social constructs likely to influence ways of thinking and acting (Au and Wong, 2000; Fan et al., 2012a; 2012b; Ho and Redfern, 2010; Liu, 2013; Tan and Snell, 2002). Past studies of interpersonal relationships involving the Chinese concept of guanxi have generated conflicting findings with respect to business personnel in the Asian region. Some, like Ang and Leong (2000), report that the practice of guanxi is negatively correlated to beliefs about corporate ethics and social responsibility. Au and Wong (2000) found that guanxi has a negative impact on auditors' ethical judgment in audit-client conflict situations. Liu et al. (2012) discovered that guanxi has a negative impact on audit quality in China. Fan et al. (2012a) also found that Chinese auditors view rent-seeking guanxi as containing undesirable elements that negatively impact ethical judgment. Recently, Liu (2013) also report Chinese auditors' moral reasoning is negatively associated with their guanxi orientations. However, other researchers report that guanxi improves business performance (Davies et al., 1995), increases efficiency and growth (Chan et al., 2002; Luo and Chen, 1997), provides certain transaction cost advantages (Standifird and Marshall, 2000), and it is not necessarily unethical in terms of Chinese auditors' favourseeking guanxi (Fan et al. 2012a). In view of these conflicting findings, the moral status of guanxi appears problematic and 'two-edged' in its application.

Western professionals doing business with their Asian counterparts, particularly Mainland China, still have difficulty appreciating the deeply rooted cultural values associated with guanxi (Hupert, 2012) although some researchers argue that networking theories in non-Chinese cultures 
share common features with their Chinese counterpart (Luo, 1997) and conceptual overlaps (Hammond and Glenn, 2004). Many are of the mistaken belief that guanxi as applied within business negotiations contains negative connotations that are innately unethical (Su et al. 2003). Moreover, Dunfee and Warren (2001) maintain that guanxi is poorly understood, that it comes in various types and ought to be examined within a particularistic paradigm. The authors of this empirical research paper strongly support this notion and examine guanxi from the perspective that it provides significant benefits for all business parties (including westerners) who recognise the cultural significance of its precepts and attempt to apply them sincerely during negotiations and ensuing business transactions. In this context, the term applied in this paper is favourseeking guanxi (Su and Littlefield, 2001).

Like all good things, guanxi can be misused and appropriated for the benefit of the few at the expense of others. This unethical type is termed rent-seeking guanxi $(\mathrm{Su}$ and Littlefield, 2001) and was first reported in Chinese business to government (B2G) transactions that unfolded during the last three decades of the country's economic expansion (Fan, 2002). Braendle et al. (2008, p. 389) claim that "this negative variant of guanxi is analogous to a two-edged sword that can harm local governance systems and hinder economic development and global business". Wilson (2008) raises further concern that rent-seeking guanxi is being applied by western investors and others as a way of getting around local (often relatively weak) regulations and secretly collaborating with their Asian partners for personal gain. Hence, a motivation for this research! How do western business professionals such as Australian accounting professionals relate to guanxi? Are they cognisant of the social networking aspects of guanxi and do they display concern about the ethicality of its variants forms?

The authors of this present study believe that guanxi (in its two-dimensional form) can be 
used in the investigation of western attitudes towards interpersonal relationships within a business context based on commonalities between guanxi and western social network theory (SNT). The literature suggests that except for Fan et al. (2012b) no equivalent research appears to have examined non-Chinese subjects' perceptions of guanxi and its impact on judgment in a business context. Fan et al. (2012b) examined the impact of guanxi orientations on the ethical judgments of a small sample of Australian born accounting students. They found that favourseeking guanxi was not a factor affecting ethical judgment but that its negative variant provided a strong negative influence. However, the Australian sample was relatively small and the absence of any literary support, presents the need to explore this matter further. Moreover, prior studies have reported inconsistent findings in relation to differences in ethical judgment between business students and practitioners such as accounting professionals (see Cohen et al. 2001; Fleming et al. 2009; Shaub 1994). Thus it is also suggested that more evidence focussing on accounting professionals is needed to validate the effect of guanxi on ethical decision-making.

The current study is different from prior studies such as Au and Wong (2000), Fan et al. (2012a; 2012b), and Liu (2013) in several ways. First, ethical intention, which is one of four ethical decision-making components (i.e., ethical sensitivity, judgment, intention, and behaviour, Rest 1986), is examined but it was not investigated in the aforementioned studies. Second, a sample of accounting professionals is used to overcome the limitation of the Fan et al. (2012b) study, which includes accounting students as a proxy for accounting professionals. Third, it appears the current study is the first to examine non-Chinese accounting professionals' guanxi orientations and their effect on ethical judgment and intentions. Finally, the current study is also the first to investigate accounting professionals' guanxi based interpersonal relationships from the perspective of public and private accountants. 
The major aim of this paper is to examine relationships between guanxi and ethical decision-making using an independent sample of Australian accounting professionals and address the following research questions:

RQ1: How do Australian accounting professionals evaluate group dynamics that suggest either positive (favour-seeking guanxi) or negative (rent-seeking guanxi) outcomes?

RQ2: Within an experimental context involving the examination of a related business scenario, how do the aforementioned evaluations influence the ethical judgments and intentions of Australian accounting professionals?

Descriptives and t-tests are used for data analysis and addressing the first research question. The hypothesis development in this current study focuses on the second research question and includes the application of path analysis.

A major premise of this research is that the concept of guanxi as applied in the study can be effectively used to assess the social networking processes associated within a western paradigm. It is believed that this study contributes to the literature in several ways. First, it further validates the notion of favour and rent seeking guanxi (Su and Littlefield, 2001) and the guanxi instrument developed by Fan et al (2012a). Second, it is the first study that examines non-Chinese subjects' perceptions of guanxi orientations using western accounting professionals applying guanxi in a universal context. As such, it provides insights into social networking that can benefit professional bodies when designing development programs. Third, it adds to the knowledge of the relationship between gaunxi and ethical decision-making in the business literature.

The following sections details the literature relating to guanxi and its relationship to social networking theory as well as its moral underpinnings (i.e., ethical judgment and intention). The 
hypothesis development with respect to the second research question and methodology will follow together with an analysis and discussion of findings.

\section{Literature review and hypotheses development}

\section{Theoretical framework of this study}

Guanxi is variously referred as interpersonal connections (Xin and Pearce 1996), personal relationships (Luo 1997) or interpersonal relationships (Su and Littlefield 2001, Chen and Chen 2004). The literal meaning of guanxi is to "pass the gate and get connected" (Lee and Dawes, 2005, p. 29) according to the two Chinese characters, guan and xi. Guan means..."a door and its extended meaning to close up" (Luo, 1997, p. 44). Xi means to..."tie up and extend into relationships" (Luo, 1997, p. 44). In a guanxi network, a person inside the door is regarded as "one of us" who can be trusted whereas a person outside the door is regarded as a stranger and not to be trusted (Luo, 1997). Guanxi can be emotionally driven based on obligations; affection exchanged based on rules of reciprocity; or a utilitarian impetus that considers personal and mutual benefits (Fan, 2002; Yang, 1993). It is commonly experienced between persons sharing a common bond or relationship, for example, family, ethnic origin, religious background, school membership etc. (Lovett et al., 1999; Steidlmeier, 1999), as well as acquaintances or even strangers sharing a common experience or challenge (Yang, 1993). Su and Littlefield (2001) identify this aspect of guanxi as 'favour-seeking' possessing moral value over the long term.

After China's economic reform and open-door policy commenced in the 1970s, there is evidence that guanxi has been applied in an opportunistic sense within the business sector particularly in 'business person to government official' relationships (Seligman, 1999; Steidlmeier, 1999). Fan (2002) used this notion to classify guanxi into two categories: 
organisational B2B (business person to business person) and bureaucratic B2G (business person to government official) based on the parties involved in the relationship. This classification is similar to Chen and Wu's (2011) guanxi classifications: business ties guanxi and government ties guanxi. Relationships between Chinese business people and government officials have been found to involve unethical practices associated with back-door deals and power dependence in modern Chinese business (Fan, 2002; Su and Littlefield, 2001). Su and Littlefield (2001) used these insights to classify guanxi into two dimensions: favour-seeking guanxi and rent-seeking guanxi. Favour-seeking guanxi is 'culturally rooted, signifying social contracts and interpersonal exchanges of resources in a collectivistic society' (Su et al. 2003, p. 310). Rent-seeking guanxi on the other hand: 'reflects on institutional norms signifying social collusion based on power exchanges in a hybrid Chinese socialist market economy' (Su et al. 2003, p. 310). Su and Littlefield's (2001) rent-seeking guanxi is similar to Yang's (1993) aspect of guanxi that includes acquaintances and strangers (e.g., in business), where the associations are more likely superficial, temporary and instrumental. Warren et al. (2004) tested two groups of Chinese business students using a scenario approach, including questionable guanxi practices. Students were able to distinguish clearly between acceptable and harmful forms of this social exchange process.

Recently, Fan et al. (2012a) proposed a 12 item two dimensional guanxi scale based on $\mathrm{Su}$ and Littlefield's (2001) classification of guanxi and Ang and Leong's (2000) 9 item scale for measuring Chinese auditors' guanxi orientations. A two-dimensional model with 8 items measuring favour-seeking guanxi and 4 items measuring rent-seeking guanxi was eventually generated based on a study of Chinese auditors (refer to Table I).

Insert Table I here 
It is believed that this guanxi instrument is capable of identifying both positive and negative aspects of social networking, and can be applied to predict ethical judgment and intention of Australian accountants. Survey responses received from a large sample of Chinese auditors clearly identified collective views relating to two forms of group behaviour (Fan et al. 2012a) and the instrument was subsequently refined and confirmed (CFA) using a small mixed sample of Australian accounting students (Fan et al. 2012b).

The theoretical framework of this study is based on Su and Littlefield's (2001) classification of guanxi and Fan et al.'s (2012a) guanxi scale. A survey methodology is used and the ethical decision-making of Australian accounting professionals focusses on ethical judgment and intention as suitable proxies for behaviour (Rest 1986).

\section{Favour-seeking guanxi and ethical judgment and intention}

Although guanxi orientations are culturally embedded in Chinese society (Davies et al., 1995), other researchers argue that networking theories in western cultures share common features with their Asian counterpart. For example, it can be compared to Blat in Russia (Michailova and Worm, 2003), Good Ol'boy networks in the United States, and Old boy networks in the United Kingdom (Ledeneva, 1998), wasta in Arab nations, and Jeitinho in Brazil (Smith et al. 2012) etc. According to Streeter and Gillespie (1993), western social networks have three important elements: boundaries, connectedness and social units. The concept of boundary in the western social networks context is similar to the concept of gate or door for guanxi, that is, a person inside the boundary/door is regarded as one of the group who merits acceptance whereas a person outside the door is regarded as a stranger and is not to be trusted (Luo, 1997). Hammond and Glenn (2004) also suggested that insider and outsider guanxi relationships are similar to the 
western social networking concepts of strong and weak ties governing associations. However, guanxi focuses more on trusted insiders while western social networks treat outsiders as new sources of information and opportunity (Hammond and Glenn, 2004). Guanxi relationships also encourage connectedness and focuses on the sharing of information and resources with group members. Luo (1997) claims that guanxi includes all western social network qualities. Redfern and Ho (2009) suggest that guanxi demands greater reciprocity obligations, while western social networks are largely non-reciprocal. In a business context, guanxi is personal in nature (Luo, 1997) while western social networks are "more commercial-based corporate-to-corporate relations" (Luo 1997, p. 47) accommodating cultural differences. Western social networks can apply to individuals, local communities or nations (i.e., social unit component) while guanxi is "the individual's connection to the whole" (Hammond and Glenn 2004, p. 26). In other words, although guanxi focuses more on the creation of personal relationships, it can also be used by an organisation to build networks with other organisations (Luo, 1997).

Moral issues associated with networking have been examined, for example Melè (2009) distinguishes three types of social exchange behaviour: utilitarian, emotional and virtuous respectively. Emotional networking attracts actors who are motivated by the pleasantry and social benefits of group association and the positive outcomes that may accrue to them personally while virtuous networking involves actors who are attracted by opportunities to contribute to group exchange, helping others achieve positive individual and group outcomes. The essence of emotional and virtuous types of social networking behaviour suggests that they are similar to favour-seeking guanxi orientations where the outcomes are identified in terms of their mutual benefits. Utilitarian networking attracts actors who are looking for economic advantage, power play and protection within group exchange. In this context, utilitarian 
networking behaviour is more related to rent-seeking guanxi, which is discussed in the next section

Vetlesen (1994) suggests that the emotional intensity and intimacy of an intragroup relationship, similar to the favour-seeking guanxi in the current study, reduces the likelihood of unethical behaviour. Jones (1991) asserts that psychological proximity is an important antecedent and people are more aware of ethical issues towards others who are close to them. Guanxi is morally acceptable from a cultural perspective (Lovett et al. 1999) and generally perceived to be ethical (Chan et al. 2002). Fan et al. (2012a) found favour-seeking guanxi was positively associated with ethical judgment based on a study of a large sample of Chinese auditors. In a recent study, Liu (2013) reported that Chinese auditors' favour-seeking guanxi orientations are positively associated with their idealistic moral positions and ethical decision-making. It is therefore expected that Australian accountants' favour-seeking guanxi orientations positively influence their ethical judgment making and intentions. As such, the following hypotheses are proposed for this study:

$\mathrm{H}_{1-1}$ : Australian accounting professionals' favour-seeking guanxi orientations are positively related to their ethical judgments.

$\mathrm{H}_{1-2}$ : Australian accounting professionals' favour-seeking guanxi orientations are positively related to their ethical intentions.

\section{Rent-seeking guanxi and ethical judgment and intention}

Rent-seeking guanxi is considered less desirable as it pertains to unethical business practices, including such activities as the application of undue pressure by dominant parties in a deal, access to bureaucratic privileges in the exercise of business transactions and various forms of 
back-door dealings (Fan et al., 2012a). Each of these activities results in an asymmetry of information between group participants, negatively affecting members and stakeholders peripheral to a business arrangement. It involves self-interest motives (e.g., relativistic reasoning) that impose a moral hazard. Such practices also encourage corruption and bribery (Fan, 2002; Su and Littlefield, 2001). As discussed earlier, there is evidence that guanxi has been applied in an opportunistic sense within the Chinese business sector, particularly in business person to government official relationships (Seligman, 1999; Steidlmeier, 1999). The culturally deviant version of guanxi (i.e., rent-seeking guanxi) emerged after its economic reform and open-door policy commenced in the 1970s (Fan et al., 2012a). However, similar practices also exist in western societies. For example, Wilson (2008) claims there is evidence that unethical guanxi type practices are fostered within a western business context and may find some degree of acceptability (or inevitability) within western business environments. Gill (2009) reports that when pressed, British accountants defend their moral positions by using selective utilitarian arguments to excuse unethical behaviour, often overlooking issues of justice, fairness and equity. Fan et al. (2012a; 2012b) found rent-seeking guanxi (including such activities as back-doordeals, dominant parties to a deal, and bureaucratic privilege) was a significant negative factor influencing the judgments of a group of Chinese auditors and Australian born accounting students. In a recent study, Fan et al (2013) also found that Australian public accountants are significantly more concerned about the issue of audit-client relationships i.e., avoid conflict of interest and familiarity, compared to Chinese auditors. It also appears that there is a positive correlation between both groups of accounting professionals' perceptions of avoiding audit-client relationships and ethical judgment making although the relationship was not statistically significant. The above studies suggest that a subject who is more accepting of rent-seeking 
guanxi is likely to yield to a desire (via his/her moral judgment and intention) to support similar forms of unethical practice. Based on the above discussion, it is expected that Australian accounting professionals' rent-seeking guanxi orientations negatively influence on their ethical judgment making and intentions. It is therefore proposed that:

$\mathrm{H}_{2-1}$ : Australian accounting professionals' rent-seeking guanxi orientations are negatively related to their ethical judgments.

$\mathrm{H}_{2-2}$ : Australian accounting professionals' rent-seeking guanxi orientations are negatively related to their ethical intentions.

\section{The roles of ethical judgment and intention}

Judgments are founded on attitudes and perceptions about a given situation, while intentions represent the desire to act on those attitudes and perceptions (Ajzen and Fishbein 1980) Their Theory of Reasoned Action (TRA) predicts that there is a positive relationship between an individual's judgment and his/her intention and that numerous field studies have identified significantly high correlations. TRA therefore postulates that individuals who make judgments (including ethical judgments) are likely to follow through with their intentions as a precursor to behaviour. In much of the previous ethics research involving surveys, percipients are requested to make judgments about a moral situation and often invited to provide a separate intentional statement about the same issue. Indirect relationships between judgment and intentions are overlooked. It is believed that the effect of accounting professionals' guanxi orientations on their ethical intention is both direct and indirect and that judgment considerations exhibit a mediating impact that can be measured independently. The following hypothesis is tested to gauge the 
moral consideration accountants provide with respect to the morality of a given situation before determining intentions.

It is proposed that:

$\mathrm{H}_{3}$ : When forming a moral intention, Australian accounting professionals will consider both positive and negative guanxi issues, which will mediate the positive relationship between judgment and intention.

Based on the above literature review and hypotheses proposed, the conceptual framework and causal relationships among the variables are presented in Figure 1. Hypotheses $\mathrm{H}_{1-1}$ and $\mathrm{H}_{2-2}$ test the direct relationship between variables (i.e., where guanxi attitudes direct intentions without passing through a judgment phase), while hypothesis $\mathrm{H}_{3}$ takes into consideration the impact that prior judgment has on intentions. Ajzen and Fishbein's (1980) TRA allows for the possibility that percipients act out of emotion, instinct, neglect etc. without giving consideration to the ethicality of the proposed action (intention).

\section{Insert Figure 1 here}

\section{Research methodology}

\section{Data collection}

A survey methodology is used in this study. The instruments include a self-administered questionnaire (Refer to Appendix I) and a short auditing ethical case (Refer to Appendix II). The self-administered questionnaire includes demographic information and 12 questions measuring respondent attitudes towards guanxi is adopted from Fan et al. (2012a). The short auditing case is acquired from the American Accounting Association (1992) (see Roxas and Stoneback 1997) and modified to suit subjects. 
A sample of Australian accounting professionals members was drawn from the Association of Certified Chartered Accounting professionals ("ACCA") of Australia and New Zealand and the Institute of Chartered Accounting professionals in Australia ("ICAA"). The method of recruitment included making a survey link available online and requesting their voluntary participation, and inviting accounting professionals to complete a questionnaire during professional development training sessions held in 2012. A total of 135 responses were collected using each of these collection methods (66\% and $34 \%$ of the total sample respectively). Incomplete responses and non-Australian respondents were excluded resulting in a final useable sample of 111. The details of selected background information of all respondents are shown in Table II below.

Insert Table II here

\section{Measurement process}

Guanxi - A confirmatory factor analysis (CFA) using AMOS (Analysis of Moment Structures) was conducted to access the goodness-of-fit of the Fan et al.'s (2012a) original 12 item model (refer to Table I) with the current sample of Australian accounting professionals. The model assessment was conducted using $X^{2}$ statistics $(p \geq .05)$ (Joreskog and Sörbom, 1993) and $X^{2} / \mathrm{df}<$ 2 (Wheaton et al., 1977) and goodness-of-fit indices such as CFI $\geq .95$ (Bentler, 1990) and RMSEA $\leq .06$ (Hu and Bentler, 1999).

The results of the CFA (i.e., $\mathrm{p}=.000, \mathrm{X}^{2}=178.16$, $\mathrm{df}=53, X^{2} / \mathrm{df}=3.36, \mathrm{CFI}=.76$ and RMSEA $=.15)$, indicate a very poor fit in the two-factor 12 items model based on the model assessment criteria. The results suggest that returning favours (reciprocation), (membership of) inner circle, social relationship and frequent cooperation represent misspecifications of the original model. Thus, it is decided that a model re-specification is necessary in order to 
determine one that better represents the same data. The significant modification indices and standardised residual covariances (larger than 2) (Joreskog and Sorborn 1993) were used as criteria to re-specify the model. The above four items are therefore deleted incrementally according to the stated criteria and the final results (i.e., $\mathrm{p}=.08, \mathrm{X}^{2}=28.15$, df $=19, X^{2} / \mathrm{df}=$ $1.48, \mathrm{CFI}=.97$ and $\mathrm{RMSEA}=.06)$ suggest that a shorter 8 -item version represents the most appropriate guanxi model for Australian accounting professionals. For this reason, this twofactor 8-item model (refer to Figure 2) was used in the data analysis for examining Australian accounting professionals' guanxi orientations and their impact on ethical judgment and intention.

The guanxi scale ranged from strongly disagree (1) to strongly agree (9). An internal consistency test (i.e. the coefficient of Cronbach Alpha) reveals that favour-seeking guanxi (four items) has a high reliability of $84 \%$ and rent-seeking (four items) guanxi is $66 \%$ which is acceptable.

\section{Insert Figure 2 here}

Ethical judgments - The business dilemma included in the survey was acquired from the American Accounting Association (1992) (see Roxas and Stoneback 1997) and modified to suit subjects (see Fan et al. 2012a). The case involves a CPA (independent external review manager) who has to decide between the need to act in accordance with applicable professional standards and the rights of affected stakeholders or acquiesce to the demands of a valued client to adjust the accounts to reflect a more favourable outcome (refer Appendix II). The business case involves a classic interfirm group interaction, where the opportunity exists for the key subjects (CPA and owner) to properly consider each other's moral position (applying favour-seeking guanxi concepts) or take advantage of the information asymmetry as well as the owner's relative 
power dominance (and overlook the interests of other stakeholders) by restating the reported accounts (rent-seeking guanxi).

Respondents were required to read the case and asked to indicate their level of agreement with three moral propositions using a 7-point Likert scale. The propositions are concerned with respondents' judgment about the ethical issues in three respects: (1) external focus - the bank and creditors may be deceived if the CPA makes the changes suggested by the client; (2) internal focus - the CPA's integrity will be compromised if he makes the changes suggested by the client; and (3) compromise - the CPA supports the client's proposal as it will ensure the on-going prosperity of his accounting firm. Proposal 3 was reverse scored before the average score of ethical judgment over the three items was calculated. An internal consistency test (i.e. the coefficient of Cronbach Alpha) reveals that the reliability of ethical judgments ( 3 items) is $70 \%$.

Ethical intention - The ethical intention is measured using the question, "under the circumstances, if you were Chuck (CPA), what is the likelihood that you will agree with the CEO's proposal to adjust the financial statements" with a 7-point Likert scale, from very unlikely (1) to very likely (7). The item was reverse scored to align with ethical judgment in the analysis.

\section{Findings and discussion}

\section{Perceptions of Australian accountants' guanxi orientations}

The overall mean scores and standard deviations of Australian accounting professionals' favourseeking and rent-seeking guanxi are $7.29(\mathrm{SD}=1.32)$ and $3.01(\mathrm{SD}=1.30)$ respectively. These results suggest that as a group they agree with the benefits associated with favour-seeking guanxi, while strongly disassociating themselves with its negative variant, rent-seeking guanxi. 
This finding is consistent with the results reported in Fan et al. (2012b) that is that Australian born accounting students' favour and rent seeking guanxi were 7.18 and 3.51 respectively.

Table III provides detailed results of professionals' guanxi orientations by comparing two independent groups, public versus private accountants. Results of one-sample t-test show the subjects from both groups rate significantly high mean scores for favour-seeking guanxi while their rent-seeking guanxi orientations are significantly lower than the mid-point value (5). An independent sample t-test reveals no significant difference between the two groups in terms of their favour-seeking and rent-seeking guanxi orientations. These results suggest that subjects from both groups tend to identify positively with favour-seeking guanxi in business but are strongly averse to rent-seeking guanxi issues.

The motivation for this current research has been to ascertain whether the Chinese concept of guanxi can be used to interpret non-Chinese subjects' interpersonal relationships in business as a suitable proxy for social networking (RQ1). The western perception of guanxi was (and still is in some respect) one of latent suspicion, founded on a belief that this concept emanated from the collectivist predisposition of many Asians (especially Chinese people) to limit trust to members of their own culture, clan or extended family. To the extent that this meant that others (including westerners) were not overly welcome within these circles, the behaviour was considered somewhat untenable or unethical. However, from a relativistic perspective, such behaviour is viewed as acceptable within the culture and, as discussed in the introduction, seen by its adherents as producing significant economic and social benefits for Chinese citizens. The positive attributes of guanxi have been incorporated in the favour-seeking element originally conceived by Su and Littlefield (2001). It is generally only when members make use of this process of socialisation to benefit themselves at the expense of others that it earns the negative 
label associated with rent-seeking guanxi. Recent studies of Chinese and non-Chinese business subjects suggest that there is much truth to the claim by researchers that there is a significant overlap between western concepts of social networking and guanxi. The results of this study of Australian accountants lend further strength to these claims.

The results of this study suggest that a sample of Australian accounting professionals (private and public) strongly associate favour-seeking guanxi as somewhat analogous to social networking processes, and that they are averse towards rent-seeking guanxi, which they view as unethical. It is unlikely that most Australian accountants would encourage such negative practices as part of normal networking relationships however actions are difficult to predict. The research findings for Australian professionals contrast with previous findings for their Chinese counterparts. Studies of Chinese auditors employed as public accountants in local firms (Fan et al. 2012a) and accounting students (Fan et al. 2012b). In-house training and appraisal of performance can sensitize accountants towards these issues, and encourage them to become familiar with guiding principles supporting ethical decision making (e.g. APES 110 for Australian accountants).

Fan et al. (2012b reveal that Chinese subjects' attitudes towards rent-seeking guanxi in particular demonstrate a degree of accommodation, suggesting that they are more accepting of questionable networking activities. In summary, the findings in this current study suggest that guanxi is reconcilable with western networking practices. Both are identifiable by Australian accountants and that these issues are taken into account when forming ethical judgments and intentions. 


\section{Ethicality of Australian accounting professionals}

The overall mean scores and standard deviations of Australian accounting professionals' ethical judgment and intention are $5.92(\mathrm{SD}=1.01)$ and $5.90(\mathrm{SD}=1.30)$ respectively. The result of Australian accounting professionals' ethical judgment is similar to the Australian born accounting students' ethical judgment (i.e., mean $=5.75 ; \mathrm{SD}=.931$ ) reported in Fan et al. (2012b) and Australian accountants' (i.e., mean $=6.28 ; \mathrm{SD}=.823$ ) reported in Fan et al. $(2013)$. The one-sample t-test reveals that accounting professionals from both groups (private and public) rate ethical judgment and intention significantly higher than the mid-score (4). Similarly, the independent sample t-test reveals that no significant difference between two groups in terms of their ethical judgment and intention. These results suggest that Australian accounting professionals (from both internal and external foci) believe that the CPA's integrity and protection of stakeholders are important, while they strongly disagree with the proposal that the CPA should accept the client request to alter the financial statements.

Insert Table III here

\section{The results of path analysis from the total sample}

A path analysis is performed to examine the causal relationships among the variables, by estimating bivariate correlations within the structural model (refer to Figure 1). Initial testing of this model suggests that the sample (including public and private accountants) does not fit in the model well. It is found that favour-seeking guanxi is not associated with ethical intention after analysing the results i.e., reviewing the modification index and correlation between these two variables, which are suggested by Byrne (2010). To overcome this, the model was modified by removing the path between favour-seeking guanxi and ethical intention. This finding suggests 
that the $\mathrm{H}_{1-2}$ that Australian accounting professionals' favour-seeking guanxi orientations are positively related to their ethical intention cannot be supported within the original model (Figure 1)

A reduced model is then presented and tested (refer to Figure 3) after deleting the path between favour-seeking guanxi and ethical intention. The results suggests that the sample fits required model specifications very well (i.e., $\mathrm{p}=.342, X^{2} / \mathrm{df}=.903, \mathrm{GFI}=.99 ; \mathrm{CFI}=1.00$ and RMSEA $=.00)$. In addition, the result of Hoelter's test (Hoelter's $.05=468$ ) suggests that the sample size in this current study is satisfactory and adequately represents the sample data (Byrne 2010). The results of causal relationships among the variables in the model are presented in Figure 3. They include the values of estimate, S.E. (standard error), C.R (critical ratio), and p value for each construct.

Insert Figure 3 here

Results show that the path between favour-seeking guanxi and ethical judgment $\left(\mathrm{H}_{1-1}\right)$ is significant at a $10 \%$ significance level (i.e. estimate $=.12 ;$ S.E. $=.07 ;$ C.R. $=1.65 ; \mathrm{p}=.099$ ) although the sample fits the model well. It is therefore concluded hypothesis $\mathrm{H}_{1-1}$ that Australian accounting professionals' favour-seeking guanxi orientations are positively related to their ethical judgments cannot be supported. However, the results show that the path between rentseeking guanxi and ethical judgment $\left(\mathrm{H}_{2-1}\right)$ is significant at a $1 \%$ significance level (i.e. estimate $=-.22 ;$ S.E. $=.07 ;$ C.R. $=-3.07 ; \mathrm{p}=.002)$ and that between rent-seeking guanxi orientations and ethical intention is also significant at a $5 \%$ significance level (i.e., estimate $=-.19$; S.E. $=.08$; C.R. $=-2.52 ; \mathrm{p}=.012$ ). These results suggest that hypothesis $\mathrm{H}_{2-1}$ that Australian accounting professionals' rent-seeking guanxi orientations are negatively related to their ethical judgments and $\mathrm{H}_{2-2}$ that Australian accounting professionals' rent-seeking guanxi orientations are negatively 
related to their ethical intentions therefore are both supported.

The results of mediating effects also show that the path is significant at $0.001 \%$ significance level (i.e. estimate $=.71 ;$ S.E. $=.10 ;$ C.R. $=7.22 ; \mathrm{p}=.000$ ). Therefore the $\mathrm{H}_{3}$ that when forming a moral intention, Australian accounting professionals will consider both positive and negative guanxi issues, which will mediate the positive relationship between judgment and intention is also supported.

\section{The results of path analysis from two sub- samples}

Public accountants and those employed within business (private accountants) engage with different job descriptions, which may affect the way they view the ethical dilemma provided in this study. Table II indicates that the test sample included 45 public and 66 private accountants. In order to compare path analyses between these two groups, testing the measurement invariance

of each measure is a necessary prerequisite (Horn, 1991). Therefore, the tests of the same factor structure (configural invariance), same factor loadings (metric invariance) and same item intercepts (scalar invariance) of a measurement instrument between two different groups were applied to the test data using a multi-group confirmatory factor analysis (MGCFA) (Jöreskog, 1971).

The results of the MGCFA suggest that both groups fit the baseline model (modified model) reasonably well but that the private accountants group (i.e., $\mathrm{p}=.524$ ) fits the model better than the public accountants group (i.e., $\mathrm{p}=.07$ ). Further, the results of the following models: metric, scalar, and factor covariances are compared against to the results of the configural model for determining invariance. Results suggest that the equivalence of a causal structure exists i.e.

- $\quad$ configural invariance $\left(p=.16, X^{2} / \mathrm{df}=1.84, \mathrm{CFI}=.97\right)$; 
- metric invariance $\left(p=.35, X^{2} / \mathrm{df}=1.12, \mathrm{CFI}=.99, \Delta X^{2}\right.$ not statistically significant $p$ $=.55, \Delta \mathrm{CFI}=.02)$;

- scalar invariance $\left(p=.12, X^{2} / \mathrm{df}=1.41, \mathrm{CFI}=.96, \Delta X^{2}\right.$ not statistically significant $p$ $=.23, \Delta \mathrm{CFI}=.03)$;

- structural means $\left(p=.30, X^{2} / \mathrm{df}=1.17, \mathrm{CFI}=.98, \Delta X^{2}\right.$ not statistically significant $p=.43$, $\Delta \mathrm{CFI}=.02) ;$ and

- factor covariances $\left(p=.55, X^{2} / \mathrm{df}=.91, \mathrm{CFI}=1.00, \Delta X^{2}\right.$ not statistically significant $p$ $=.71, \Delta \mathrm{CFI}=0.02)$.

If the traditional invariance-testing approach is applied, based on the $X^{2}$ difference test as the basis for determining evidence of equivalence, then it is concluded that the causal structure model is equivalent between the two employment types. The above results suggest that both groups have a same factor structure and factor loadings across dimensions. Group respondents responded to the scale items in a similar fashion and demonstrate similar means for each construct. The correspondence of factors between two groups is also similar.

Now the causal structure invariance is established, the results of path analysis from two groups are compared and presented in Figures 4-1 and 4-2.

Insert Figures 4-1 and 4-2 here

The summary of regression findings provided in Figures 4-1 and 4-2is interesting as it applies to the modified path model illustrated in Figure 3. Unfortunately, the empirical testing of the direct relationship between favour-seeking guanxi and intention cannot be ascertained given the minimum path model specifications not being satisfied. However it is possible to identify significant differences in the way private accountants use guanxi principles to decide how to process their moral judgments/intentions when compared to public accountants. 
Within their separate groups the accountants deal with the business dilemma in significantly divergent ways. Both employment types act predictably when relating judgments to intentions. Once making a judgment, there is a strong likelihood that both types will draw equivalent intentions. That is, judgments, per se predict moral intentions to act (strong positive relationships, with $p<0.05$ ). How they formulate those judgments however, differ significantly. Private accountants use both favour-seeking and rent-seeking guanxi attitudes to determine judgments (positive and negative relationships respectively with $p<0.05$ in both instances). Public accountants however appear not to consider these group dynamics (i.e., guanxi principles) as factors predicting how they ought to behave.

As discussed above (refer Figure 3), it is not possible, using the given sample, to ascertain the differential direct influence of favour-seeking guanxi on intentions for the two employment types. However, it does appear (refer Figure 4-1) that public accountants are more likely to react spontaneously when it comes to stating an intention, based on their rent-seeking guanxi attitudes (significant negative relationship, $p<0.1$ ). That is, public accountants who are relatively supportive of the negative rent-seeking guanxi issues are significantly less likely to disagree with the suggestion that the CPA in the case study make adjustments in accordance with the client's request. Private accountants on the other hand, show no significant predilections in this direction (relationship between rent-seeking guanxi and intention non-significant).

The set of path analysis results summarized in Figures 4-1 and 4-2 provide evidence of an interesting anomaly affecting Australian accountants, depending on whether they are employed by accounting practices (e.g., Big 4 firms) or individual businesses. Both sub-groups are equally well represented in the sample (45 and 66 respectively). As discussed above, private accountants draw upon their guanxi principles (both favour and rent seeking) when making ethical 
judgments, whereas public accountants refer to other untested factors and appear not to be influenced by these antecedents to moral behaviour. In this instance, it is necessary to refer to the case study provided to respondents. Public accountants are more likely to relate to the CPA, who is challenged to make adjustments for the client given his accounting firm's relative dependence on that company (represents $25 \%$ of business). Given that the scale ratings for the two groups are not significantly different (refer Table III), this suggests that some public accountants may take a strong aversion towards the dominance of the client in the group setting, while others might be inclined to acquiesce to the demands. This issue deserves further investigation. With respect to hypothesis $\left(\mathrm{H}_{3}\right)$, the resulting empirical analysis points to acceptance in the case of private accountants, but rejection for public accountants.

Again, further differences are identified for the two employment types. Public accountants appear inclined to act spontaneously when considering rent-seeking guanxi issues in forming intentions to act. Those who support the CPA's decision to accept the client's request to manipulate the reports appear more likely to consider unethical group practices. Such a reaction presupposes that the accountant acts in a way that he/she fails to consider the consequences or ethical guidelines affecting judgment. This might also be a function of the nature of the case, where the CPA is identified as being under considerable pressure to respond to the dominant group actor's demands, something public accountants can relate to. Again, further research could address these issues.

\section{Conclusions}

The aim of this study is to examine how Australian accounting professionals relate to guanxi and the impact on their ethical judgments and intentions. Favour-seeking guanxi was found to be a 
significant factor influencing the ethical judgment of Chinese auditors in Fan et al. (2012a) but did not significantly influence the ethical judgments of accounting students in Fan et al. (2012b) or for the 111 Australian accounting professionals surveyed in this current study. There is in fact no convincing evidence for proposing that support for social networking would necessarily encourage an accounting professional to act unethically in their business dealings. However, the evidence provided in this paper does suggest that the opportunity exists for some professionals to consider applying questionable networking practices if they believed they could gain personal benefits from doing so. The path analyses undertaken in this study do not exclude such possibilities. Unfortunately, the model specification requirements for the sample were not sufficient to allow the testing of the direct effect of favour-seeking guanxi on intentions, resulting in the outcome that the hypothesis could not be supported.

This study has theoretical and practical implications. From a theoretical perspective, it is evident that guanxi concepts can be considered useful when researching the attitudes and behaviours of western professionals. There is clear evidence that the positive and negative constructs of guanxi are identifiable by Australian accountants and that they can be used to predict ethical preferences. This study validates the notions of Warren et al. (2004) that guanxi is somewhat like a double-edged sword that has now been demonstrated to apply in non-Chinese cultural contexts. The study also reaffirms previous work (i.e., Fan et al. 2012b) that westerners are more likely to be averse to rent-seeking guanxi compared to their Asian (Chinese) counterparts. As Du and Tang (2005, p. 291) pointed out, "the most difficult aspect of doing business in China is "corruption"', which may be seen to be indicative of rent-seeking guanxi in the current study. 
Most of the positive and negative items that relate to guanxi (refer Table 1) are clearly identifiable by Australian accountants and they are just as likely to have their ethical judgments and intentions impaired by their support of the latter. Employers need therefore to ensure that their accounting professionals are properly sensitized towards the negative outcomes that can arise as a result of various social exchanges. Codes of conduct should be supported and accountants continually encouraged to participate in periodic training development programs provided by their professional bodies. Firms should also ensure they establish good ethical climates that foster good practices. In-house training and appraisal of performance can sensitize accountants towards these issues, and encourage them to become familiar with guiding principles supporting ethical decision making (e.g. APES 110 for Australian accountants).

More importantly, this research exposes accountants (particularly public accountants) to the problems associated with taking action before considering all issues (i.e., rent-seeking guanxi issues). Accountants who are aware of the moral stresses associated with group interaction (interfirm and intrafirm), are likely to form better moral judgments and consider all relevant issues before acting on those judgments. All accounting professionals regardless of their cultural heritage need to be aware of the familiarity and self-interest threats to independence and objectivity that arise if they fail to consider these differences and allow themselves to be involved in negative aspects of guanxi during their business dealings.

There are several limitations to the findings of this study. A non-response bias exists in relation to the nature of the survey, which was voluntary and aimed at a less than random group of accounting professionals. The sample of accountants is small and the study deserves to be replicated using larger more representative groups. Furthermore, the study is also limited due to the sample was drawn in Australia, which justifies further research e.g., examining non-Chinese 
accounting professionals working in China or other Chinese societies such as Hong Kong, Taiwan etc.

\section{References}

Ajzen, I. and M. Fisbein (1980), Understanding attitudes and predicting social behaviour, Engelwood Cliffs, NJ, Prentice Hall.

Ang, S. and Leong, S. (2000), Out of the mouths of babes: business ethics and youths in Asia. Journal of Business Ethics, Vol. 28 No. 2, pp.129-144.

Au, A. K. M. and Wong, D. S. N. (2000), The impact of guanxi on the ethical decision-making process of auditors - an exploratory study on Chinese CPAs in Hong Kong. Journal of Business Ethics, Vol. 28 No. 1, pp. 87-93.

Bentler, P. M. (1990), Comparative fit indexes in structural models. Psychological Bulletin, Vol. 107 No. 2, pp.238-246.

Braendle, U.C., Gasser, T. and Noll, J. (2008), Corporate Governance in China. Is economic growth potential Hhindered by Guanxi? Business and Society Review Vol. 110 No. 4, pp.389-405

Byrne, B. M. (2010). Structural equation modeling with AMOS basic concepts, applications, and programming. Routledge, New York.

Chan, R. Y. K., Cheng, L. T. W. and Szeto, R. W. E. (2002), The dynamics of guanxi and ethics for Chinese executives. Journal of Business Ethics, Vol.41, pp.327-336.

Chen, X. and Wu, J. (2011), Do different guanxi types affect capability building differently? A contingency view. Industrial Marketing Management, doi:10.1016/j.indmarman. 2010.12.014.

Chen, X. P., and Chen, C. C. (2004), "On the Intricacies of the Chinese Guanxi: A Process Model of Guanxi Development", Asia Pacific Journal of Management, 21(3): pp. 305324.

Cheung, G. W., and Rensvold, G. W. (2002), Evaluating good-of-fit indexes for testing measurement invariance. Structural Equation Modellings, 9(2), pp. 233-255

Cohen, J. R., Pant, L. W. and Sharp, D. J. (2001), An examination of differences in ethical decision-making between Canadian business students and accounting professionals.' Journal of Business Ethics, 30, pp.319-336.

Davies, H., Leung, T. K. P., Luk, S. T. K. and Wong, Y. (1995), The benefits of "guanxi"- the value of relationships in developing the Chinese market. Industrial Marketing Management, Vol. 24 No. 3, pp.207-214.

Du, L. and Tang, T. L. (2005), Measurement invariance across gender and major: The love of money among university students in People's Republic of China. Journal of Business Ethics, Vol. 59, pp.281-293.

Dunfee T.W. and Warren, D.E. (2001), Is guanxi ethical? A normative analysis of doing business in China. Journal of Business Ethics, Vol. 32, pp.191-204.

Fan, Y. (2002), Guanxi's consequences: personal gains at social cost. Journal of Business Ethics, Vol. 38, pp.371-380. 
Fan, Y. H., Woodbine, G. and Scully, G. (2012a), Guanxi and its influence on the judgment of Chinese auditors. Asia Pacific Business Review, Vol. 18 No.1, pp.83-97.

Fan, Y. H., Woodbine, G., Scully, G. and Taplin, R. (2012b), Accounting students' perceptions of guanxi and their ethical judgment. Journal of Business Ethics Education, Vol. 9, pp. 27-50.

Fan, Y. H., Woodbine, G., Chen, W., (2013), A study of Australian and Chinese accountants' attitudes towards independence issues and the impact on ethical judgements. Asian Review of Accounting, Vol. 21, No. 3, pp.205-222

Fleming, M., D., Romanus, R. N., and Lightner, S. M, (2009), The effect of professional context on accounting students' moral reasoning. Issues in Accounting Education, Vol 24 (1), pp.13-30.

Gill, M. (2009). Accountants' truth. Knowledge and ethics in the financial world. U.K.: Oxford University Press.

Hair, J.F., Black, W.C., Babin, B.J. and Anderson, R.E. (2010), Multivariate Data Analysis: A global perspective, $7^{\text {th }}$ Edition, Pearson, N.Y.

Hammond, S. C. and Glenn, L. M. (2004), The ancient practice of Chinese social networking: guanxi and social network theory. E:CO Special Double Issue, Vol. 6 No. 1-2 Fall, pp.24-31.

Ho, C. and Redfern, K. A. (2010), Consideration of the role of guanxi in the ethical judgment of Chinese managers. Journal of Business Ethics, Vol. 96, pp.207-221.

Horn, J. L. (1991). Comments on "Issues in Factorial Invariance". In L. M. Collins \& J. L. Horn (eds.), Best methods for the analysis of change, (pp. 117-44). American Psychological Association, Washington, DC.

Hu, L. and Bentler, P. M. (1999), Cutoff criteria for fit indexes in covariance structure analysis: Conventional criteria versus new alternatives. Structural Equation Modeling, Vol. 6, pp.1-55.

Hunt, S. D. and Vitell, S. J. (1986), A general theory of marketing ethics. Journal of Macromarketing, Vol 6(Spring), pp.5-16.

Hunt, S. D. and Vitell, S. J. (1993), The general theory of marketing ethics: A retrospective and revision. In N. Smith and J. Quelch (eds.), Ethics in marketing, (pp. 775-784). Richard D. Irwin, Homewood, IL

Hupert, A. (2012), Guanxi for the busy American. Kindle edition, U.S.

Jones, T. M. (1991). Ethical decision making and behavior among marketing ethics: A crosscontingent model. Academy of Management Review, Vol. 7, pp.263-271.

Jones, G. E. and Kavangh, M. J. (1996), The experimental examination of the effects of individual and situational factors on unethical behavioral intentions in the workplace. Journal of Business Ethics, Vol. 15, pp.511-523.

JJöreskog, K. G. and Sörbom, D. (1993), LISREL 8: Structural equation modeling with the SIMPLIS command language. Scientific Software International, Chicago.

Ledeneva, A. V. (1998), Russia's economy of favors: Blat, networking and information Exchange. Cambridge University Press, Cambridge.

Lee, D. Y. and Dawes, P. L. (2005), Guanxi, trust, and long-term orientation in Chinese business markets. Journal of International Marketing, Vol. 13 No. 2, pp.28-56.

Little, T. D. (1997), Mean and covariance structures (MACS) analyses of cross-cultural data: Practical and theoretical issues. Multivariate Behavioral Research, Vol. 32, pp.53-76. 
Lovett, S., Simmons, L. C. and Kali, R. (1999), Guanxi versus the market: ethics and efficiency. Journal of International Business Studies, Vol. 30 No. 2, pp.231-247.

Liu, M. (2013), Effect of guanxi and ethical orientations on Chinese auditors' ethical reasoning. Managerial Auditing Journal, Vol. 28 No. 9, pp. 815-837

Luo, Y. (s1997). Guanxi: Principles, philosophies, and implications. Human Systems Management, Vol. 16 No. 1, pp.43-51.

Luo, Y. and Chen, M. (1997), Does guanxi influence firm performance? Asia Pacific Journal of Management, Vol. 14, pp.1-16.

Mele, C. (2009). Value logic in network. Sinergie

Michailova, S. and Worm, V. (2003), Personal networking in Russia and China: blat and guanxi. European Management Journal, Vol. 21 No. 4, pp.509-519.

Redfern, K. and Ho, C. (2009), Toward a multi-dimensional understanding of guanxi: a study of business ethics in the Chinese baking industry. The Business Review, Cambridge, vol. 12 No. 2, pp.38-43.

Rest, J. (1986). Moral Development. Advances in Research and Theory. Praeger: New York

Roxas, M.L. and Stoneback, J.Y., (1997). An investigation of the ethical decision-making

process across varying cultures. The International Journal of Accounting, 32 (4), 503-535.

Seligman, S. D. (1999), Guanxi: Grease for the wheels of China. The Chinese Business Review, Vol. 26 No. 5, pp.34-38.

Shaub, M. (1994), An analysis of the association of traditional demographic variables with the moral reasoning of auditing students and auditors. Journal of Accounting Education, Vol 12(1), pp.1-26.

Smith, P.B., H.J. Huang, C. Harb and C. Torres. (2011). How distinctive are indigenous ways of achieving influence? A comparative study of guanxi, wasta, jetinho and 'pulling strings'.

Journal of Cross-Cultural Psychology. Online version available at http://jcc.sagepub.com/content/43/1/135.

Standifird, S. S. and Marshall, R. S. (2000), The transaction cost advantage of guanxi-based business practices Journal of World Business, Vol. 35 No. 1, pp.21-42.

Steidlmeier, P. (1999), Gift giving, bribery and corruption: Ethical management of business relationship in China. Journal of Business Ethics, Vol. 20, pp.121-132.

Streeter, C. L. and Gillespie, D. F. (1993), Social network analysis. Journal of Social Service Research, Vol. 16 No. 1, pp.201-222.

Su, C. and Littlefield, J. E. (2001), Entering guanxi: a business ethical dilemma in mainland China? Journal of Business Ethics, Vol. 33 No. 3, pp.199-210.

Su, C., Sirgy, M. J. and Littlefield, J. E. (2003), Is guanxi orientation bad, ethically speaking? A study of Chinese enterprises. Journal of Business Ethics, Vol. 44, pp.303-312.

Tan, D. and Snell, R. S. (2002), The third eye: Exploring guanxi and relationship morality in the workplace. Journal of Business Ethics, Vol. 41, pp.361-384.

Vetlesen, A. J. 1994. Perception, empathy, and judgment: An inquiry into the preconditions of moral performance. University Park, PA: Pennsylvania State University Press.

Warren, D .E., Dunfee, T.W. \& Li N. (2004), Social Exchange in China: The double-edged sword of guanxi. Journal of Business Ethics, Vol. 55, pp.355-372.

Wheaton, B., Muthén, B., Alwin, D. F. and Summers, G. F. (1977), Assessing reliability and stability in panel models. In D. R. Heise (ed.), Sociological methodology, (pp.84-136). Jossey-Bass, San Francisco. 
Wilson, S. (2008), Law Guanxi: MNCs, state actors, and legal reform in China, Journal of Contemporary China, Vol. 54 No. 54, pp.25-51

Yang, K. S. (1993), Chinese social orientation: an integrative analysis. In L. Y. Cheng, F. M. C. Cheung and C. N. Chen (eds.), Psychotherapy for the Chinese: selected papers from the first international conference, (pp.19-56). The Chinese University of Hong Kong, Hong Kong.

\section{Appendix I Guanxi orientation*}

a. Favour-seeking guanxi

1. In business, it is important to maintain a good network of relationships

2. Maintaining good relationships is the best way to enhance business

3. Doing business involves knowing the right people

4. Developing the right contacts helps in the smooth running of a business

5. Building and maintaining social relationships with others is important in case their services are needed in the future**

6. Being in the 'inner' circle helps in obtaining preferential treatment**

7. Returning favour for favour is part of doing business**

8. Frequent cooperation reduces problems in business relationships**

b. Rent-seeking guanxi

1. Back-door deals are alright as long as those involved in the process benefit

2. Bureaucratic privilege, which benefits some parties at the expense of others is to be expected

3. It is acceptable behavior for the dominant parties to a deal to make all the decisions.

4. Gift giving is an important aspect in business success

* Source: Fan et al. (2012a). The guanxi scale is extracted from survey questionnaire. The respondents were asked to circle the one answer that best describes his/her view of each question using a 9-point Likely scale

** These items were eliminated from the original model as they did not fit the model with the current sample after a CFA conducted. Refer to Figure 2.

\section{Appendix II Ethical decision-making case**}

CPA Chuck Adkins has just completed a year-end review and tax return for XYZ, Inc. XYZ is a five-year-old privately held company. During the five years, the business has grown substantially and has generated a comfortable living for its owner and CEO, Jack Hanson. In order to grow further, Hanson is considering taking the company public.

The company has failed, as many closely held businesses do, to keep careful records. Until now XYZ had not had an outside accountant. Consequently, most of the company's financial history is to be found in various loan applications and tax returns over the years. In anticipation of doing an audit when the company goes public, Adkins has been reviewing all of the past records that are available. Adkins review of the company's books has revealed various "soft spots" in the records as well as potentially undervalued assets. 
In conversations with Adkins, Hanson has indicated that he plans to approach Big Bank for working capital to fuel expansion. The line of credit will be secured by all receivables, inventory, and equipment owned by the company. Hanson has been told that the line of credit has a formula related to fluctuating receivable and inventory levels and a fixed amount for the equipment.

The bank requires the review by an accountant as part of the loan approval process. After completing the review for the year just ended, Adkins calls Hanson and tells him that his company has suffered a significant loss of $\$ 125,000$. Sales during the prior three years had run between $\$ 1.5$ and $\$ 2$ million. Hanson responds that he had expected a loss like that because XYZ lost a major contract. Unless new business is found to replace the contract, things could be tight for a few years.

After reviewing the financial statements with Adkins, Hanson tells him, "You know, if Big Bank sees these statements, we're sunk. We'll never get the line of credit." Adkins assures him that the company still has significant net worth despite a bad year. He doesn't think that Big Bank will reject the loan application over the one-year loss. Adkins suggests that Hanson go to the bank with a plan to deal with the problem, citing the five-year history of growth. Hanson is not convinced; the bank has made it clear that it would take a close look at current performance prior to extending the line of credit. If the credit isn't forthcoming, XYZ will have a hard time paying suppliers on time. If materials or parts are held up, delivery deadliness will not be met and the income situation will deteriorate further.

Hanson asks Adkins, "How can we make this look better? You accountants know that there are various ways to interpret and report data. Certainly you know how to change the numbers to present a better picture. Can't the undervalued assets be restated? What about all that goodwill we have generated by quality products and prompt service? That must be worth something. Or what about receivables? Maybe all those accounts that you wrote off weren't all that bad; perhaps we could carry some of them for a while longer. Tell me, what can we do now?"

Hanson's attitude makes Adkins uneasy. At the same time, XYZ is in an industry where Adkins's accounting firm has been trying to gain a foothold for some time. The XYZ account could mean as much as $25 \%$ of his firm's income in terms of all of the opportunities for service. In today's competitive market, every prospective client is valuable.

Please circle the answer that best describes your view to each statement.

1. I believe that the bank and the creditors may be deceived if Adkins makes the changes suggested by Jack Hanson.

2. I believe that if Adkins makes the changes suggested by Jack Hanson his integrity will be impaired

3. If Adkins makes the changes suggested by Jack Hanson because he wanted his own future business assured then I believe his action would be:

4. Under the circumstances, if you were Chuck, what is the likelihood that you will agree with Jack Hanson's proposal to adjust the financial statements?

(** the ethical case is extracted from survey questionnaire. The respondents were asked to circle the one answer that best describes his/her ethical judgment and intention using a 7-point Likely scale from 1 Strongly disagree (1) to Strongly agree (7) and Very unlikely (1) to Very likely (7) respectively) 
Table I: Two dimensional guanxi*

\begin{tabular}{l|l}
\hline Favour-seeking guanxi & Rent-seeking guanxi \\
\hline Maintain a good network & Back-door deals \\
Knowing the right people & Bureaucratic privilege \\
Developing the right contacts & Dominant parties to a deal (power exchange) \\
Building and maintaining social relationships & Gifts giving \\
Being in the "inner" circle & \\
Returning favour for favour & \\
Maintaining good relationships & \\
Frequent cooperation & \\
\hline *Source: Fan et al. (2012a) &
\end{tabular}

Table II: Selected background information on respondents

\begin{tabular}{llrr}
\hline & & Sample size & $\%$ \\
\hline Gender & Male & 65 & 59 \\
& Female & 46 & 41 \\
Education level & Bachelor & 35 & 32 \\
& Master & 49 & 44 \\
& Diploma & 27 & 24 \\
Age & $23-30$ & 16 & 15 \\
& $21-40$ & 36 & 33 \\
& $41-50$ & 23 & 21 \\
& 51 above & 36 & 31 \\
Current employment & & & \\
& Public accountants & 45 & 41 \\
& Private accountants & 66 & 59 \\
\hline
\end{tabular}

*Public accountants employed by firms devoted to providing accounting/auditing services

** Private Accountants include individuals employed in companies and other firms. 
Table III: Descriptive results of guanxi orientations and ethical decision-making

\begin{tabular}{|c|c|c|c|c|}
\hline & Mean* & SD & t-Statistic & $p$-Value \\
\hline \multicolumn{5}{|c|}{ One sample t-test (applied to scale mid-point): } \\
\hline \multicolumn{5}{|c|}{ Favour-seeking guanxi } \\
\hline Public accountants & 7.34 & 1.35 & 11.65 & .000 \\
\hline Private accountants & 7.26 & 1.31 & 13.96 & .000 \\
\hline \multicolumn{5}{|l|}{ Rent-seeking guanxi } \\
\hline Public accountants & 2.92 & 1.31 & -10.66 & .000 \\
\hline Private accountants & 3.07 & 1.30 & -12.08 & .000 \\
\hline \multicolumn{5}{|l|}{ Ethical judgment } \\
\hline Public accountants & 5.74 & 1.12 & 10.44 & .000 \\
\hline Private accountants & 6.04 & .92 & 17.92 & .000 \\
\hline \multicolumn{5}{|l|}{ Ethical intention } \\
\hline Public accountants & 5.64 & 1.45 & 7.62 & .000 \\
\hline Private accountants & 6.08 & 1.17 & 14.44 & .000 \\
\hline \multicolumn{5}{|c|}{$\begin{array}{l}\text { Independent sample t-test (Public } v \text {. Private } \\
\text { accountants): }\end{array}$} \\
\hline Favour-seeking guanxi & \multicolumn{4}{|c|}{$\begin{array}{l}\text { Mean difference }=.087 ; \\
\text { Std. error difference }=.257 ; \quad \text { sig. }=.736\end{array}$} \\
\hline Rent-seeking guanxi & \multicolumn{4}{|c|}{$\begin{array}{l}\text { Mean difference }=-1.555 ; \\
\text { Std. error difference }=.252 \text {; }\end{array}$} \\
\hline Ethical judgment & \multicolumn{4}{|c|}{$\begin{array}{l}\text { Mean difference }=.295 \\
\text { Std. error difference }=.195\end{array}$} \\
\hline Ethical intention & \multicolumn{4}{|c|}{$\begin{array}{l}\text { Mean difference }=-.431 ; \\
\text { Std. error difference }=.249 \text {; }\end{array}$} \\
\hline
\end{tabular}

*Represents the grand mean for guanxi items along a nine-point scale. $1=$ strongly disagree to $9=$ strongly agree

*Represents the grand mean for ethical judgment and intention items along a seven-point scale. $1=$ strongly disagree to $7=$ strongly agree 


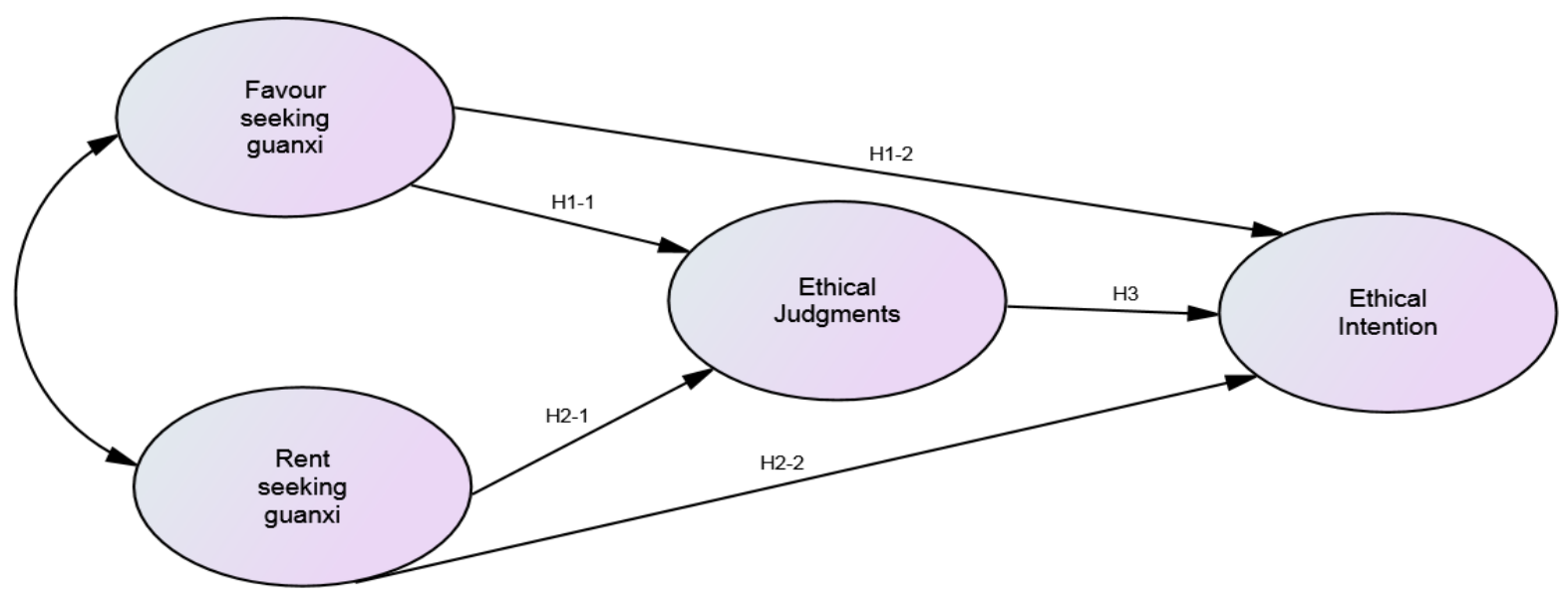

Figure 1: The causal relationships among guanxi, judgment and intention 


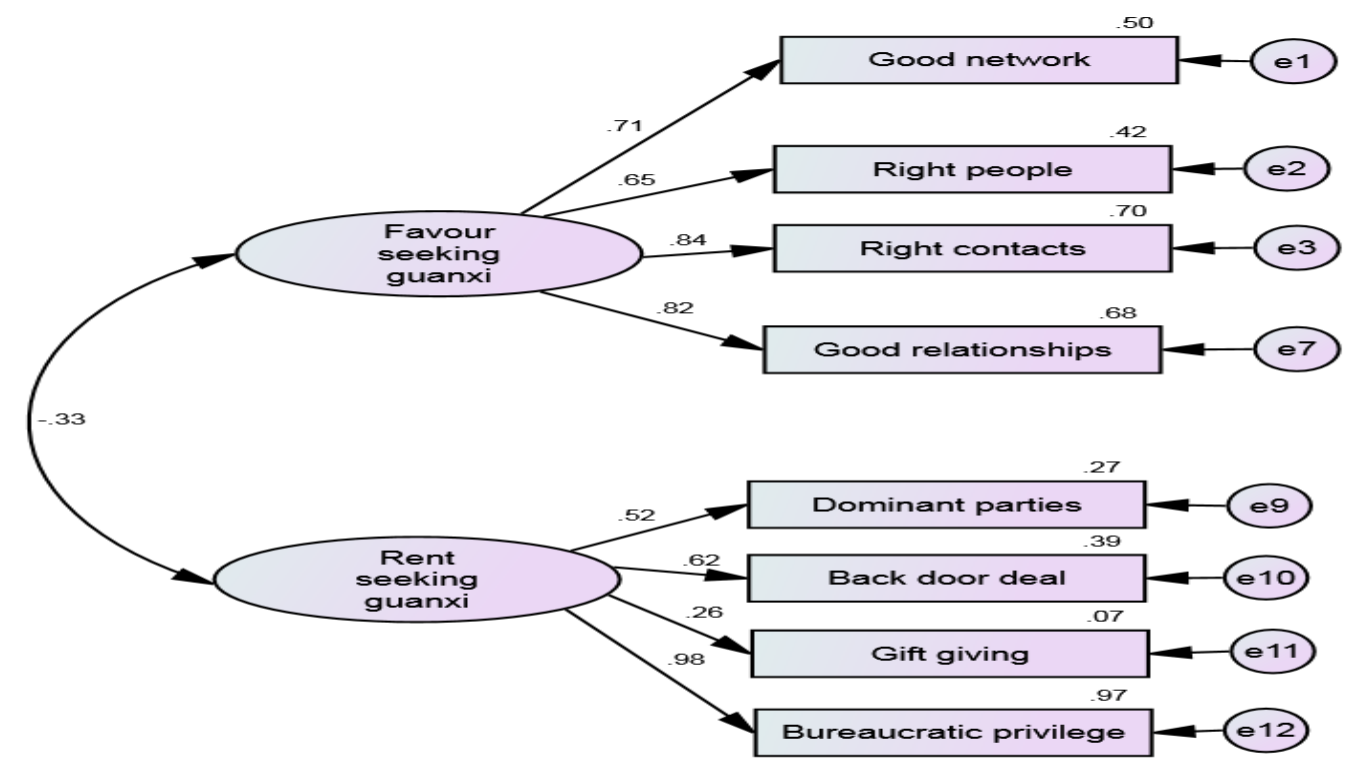

Figure 2: Australian accounting professionals' guanxi orientations (standardised estimates)

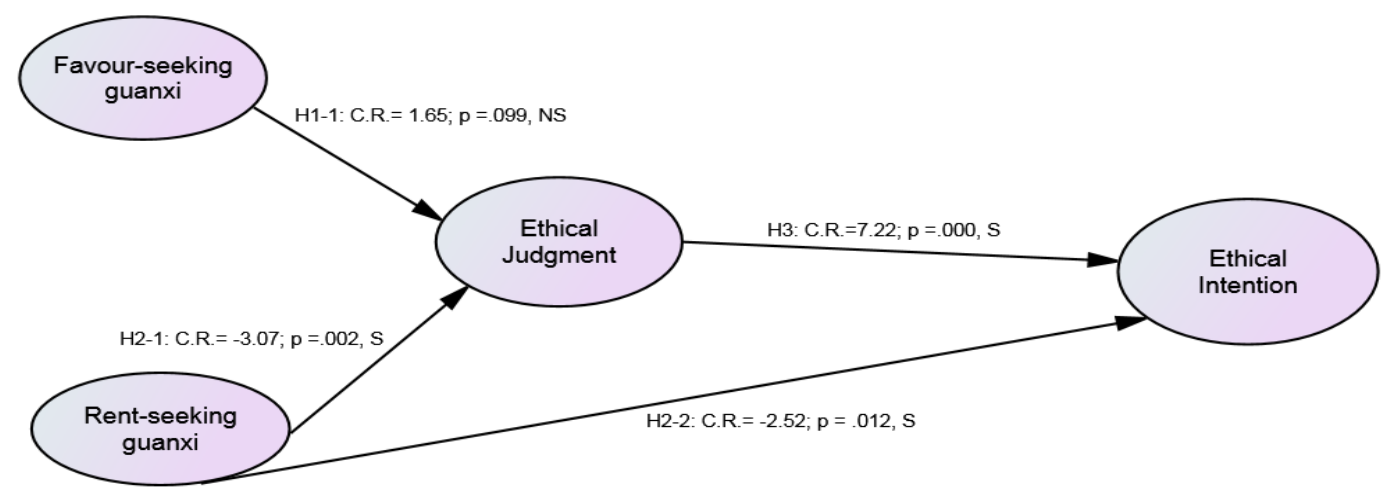

Figure 3: The results of path model (two groups) 


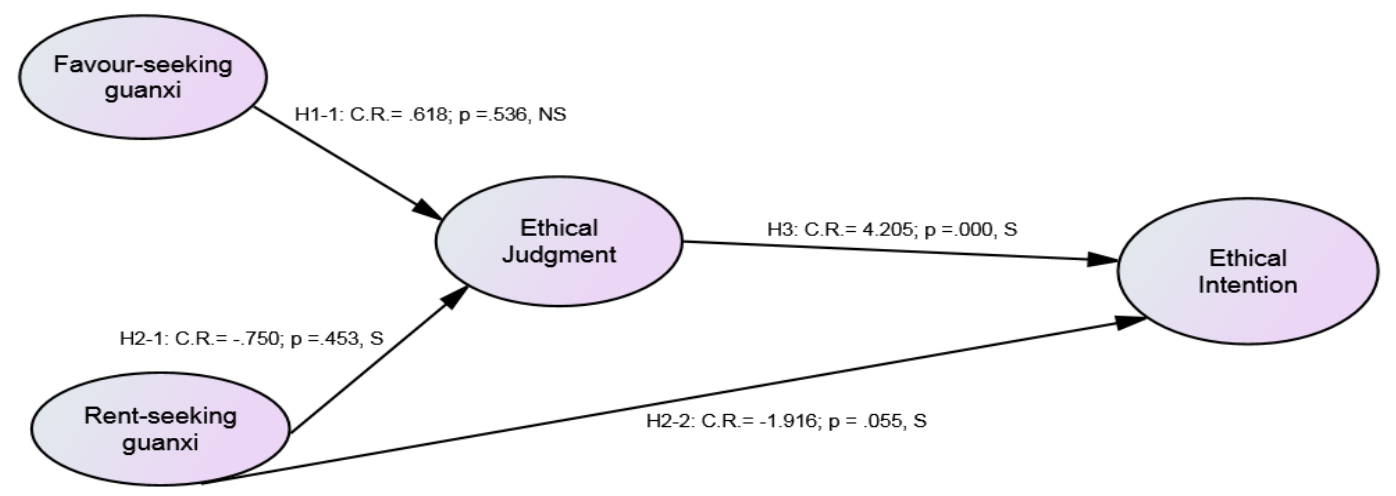

Figure 4-1: The results of path model (public accountants)

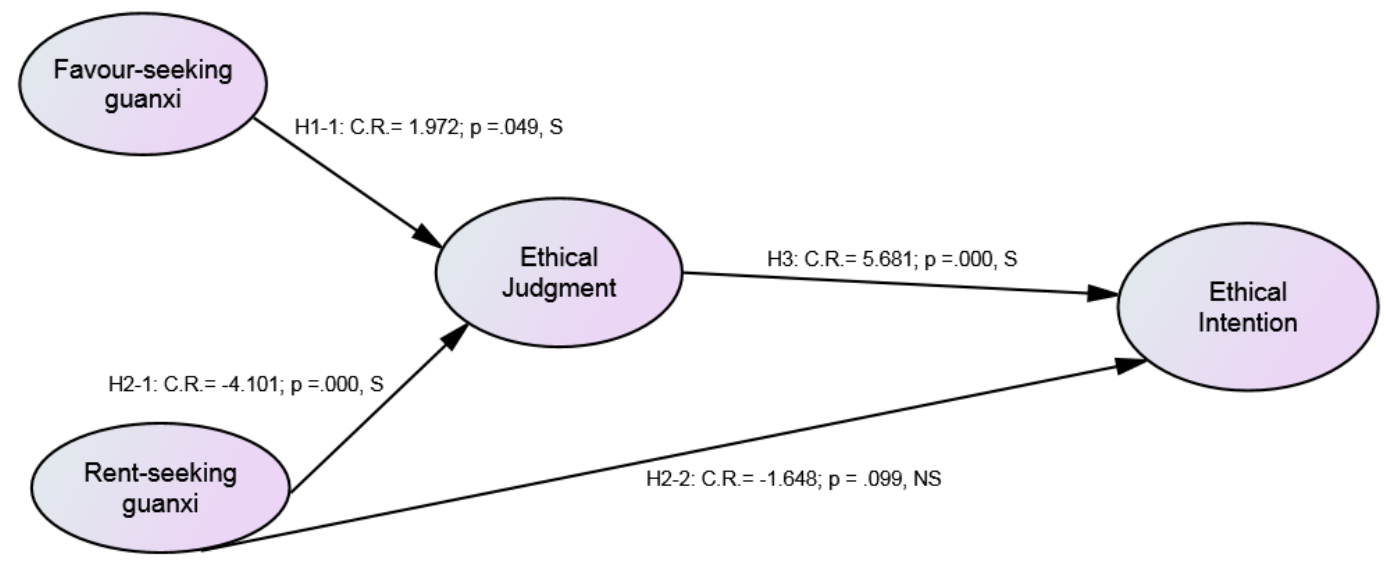

Figure 4-2: The results of path model (private accountants) 